\title{
SYNTHESIS OF LEVER-BLADE DAMPERS WITH ENHANCED MECHANICAL STRUCTURE
}

Introduction. The torsion suspensions are in wide use at contemporary automotive engineering. Such suspension operating elements are torsions: elastic bars, loaded with torsion force. The torsion bars are traditionally used as suspension structure of armored vehicles and cars. Moreover, torsion bars in automobile suspensions can be used both as the elastic element, and as an auxiliary device, i.e. a stabilizing bar, purposed to create the vehicle's anti-roll resistance. Given that the torsion bar represents only an elastic element, the question of energy dissipation in suspensions including such bar is quite relevant. Firstly the problem of improving the torsion bar suspensions' energy dissipation has been solved in the UK, when for the first time in parallel with the torsion bars the hydraulic piston shock absorbers have been installed. Due to this the suspension's tendency to body longitudinal vibrations has been eliminated with greatly improved smoothness of suspension's course. Currently, in addition to said hydraulic piston or gas shock absorbers, characterized by the movable member's translational motion respectively to the housing in wide use at torsion suspension structure are lever shock absorbers (piston and vane types), characterized by the movable member's rotational movement respectively to the housing. So on each side of the T-72 tank (USSR), the first, second and sixth suspensions are equipped with three lever-blade dampers (lever rotation angle of $87^{\circ}$ ) [1].

The existing hydraulic shock absorbers are usually implementing a performance, consisting of digression and regression areas, that is due to the throttle and the throttle-valve modes of operation. However, increasing demands to the suspension of the vehicle require the implementation of other performance characteristics not implementable when the existing shock absorbers' passive constructions using due to their functionality limitations. An alternative in the form of active damping systems' application with respect to their high cost and additional energy consumed is selective being welljustified only for original unique or cost-expensive equipment [2]. Therefore, the synthesis of passive hydraulic shock absorbers with advanced features, making possible to realize the desired (target) performance represents an actual applied scientific problem.

Recent researches and publications analysis. Studies analyzing the torsion suspension dissipative elements show that $70 \%$ of them are piston hydraulic shock absorbers and $30 \%$ refer to the levertype absorbers $[2,3]$. Such a distribution by type is due to the fact that the issues both in design and manufacturing technology of the piston hydraulic shock absorbers are well addressed, and their performance, for lack of a better, does satisfy customers to some extent. However, the several piston constructions use for torsion suspensions' shock absorbers is impossible because of their size. In such cases, the simple and compact lever-piston or lever-vane hydraulic dampers are applied (Fig. 1).

They are recommended for use at vehicles with a rigid suspension and a low rate of motion $[2,4]$. They may be single- or double-acting, with a horizontally or vertically extended casing, which houses the vanes or pistons movable by means of levers.

Despite their structural differences, these devices are similar by operation principle and from a physical point of view. Thus, the lever-piston shock absorber operates as follows (Fig. 1, a). The damper has a double piston 2, which houses the non-return valves. The lever 4 can move the piston 2 in one direction or another, thus fulfilling compression and rebound strokes of the suspension. During

DOI 10.15276/opu.1.45.2015.04

(C) I.I. Sydorenko, Zhang Yi Heng, 2015

МАШИНОБУДУВАННЯ. ТЕХНОЛОГІЯ МЕТАЛІВ. МАТЕРІАЛОЗНАВСТВО 
compression, the hydraulic fluid flows from the cavity 3 into the cavity 1 through throttle (calibrated) groove in the valve stem 5 and the gap on valve seat 6 , thus overcoming the weak resistance of the internal spring (throttle operation mode). When a sudden pressure increase the working fluid in the cavity 3 overcomes the resistance of valve's rigid outer spring 6 and increases the orifice between the valve and body (valve mode). While rebound the working fluid is flowing in reverse direction from the cavity 1 into the cavity 3 .
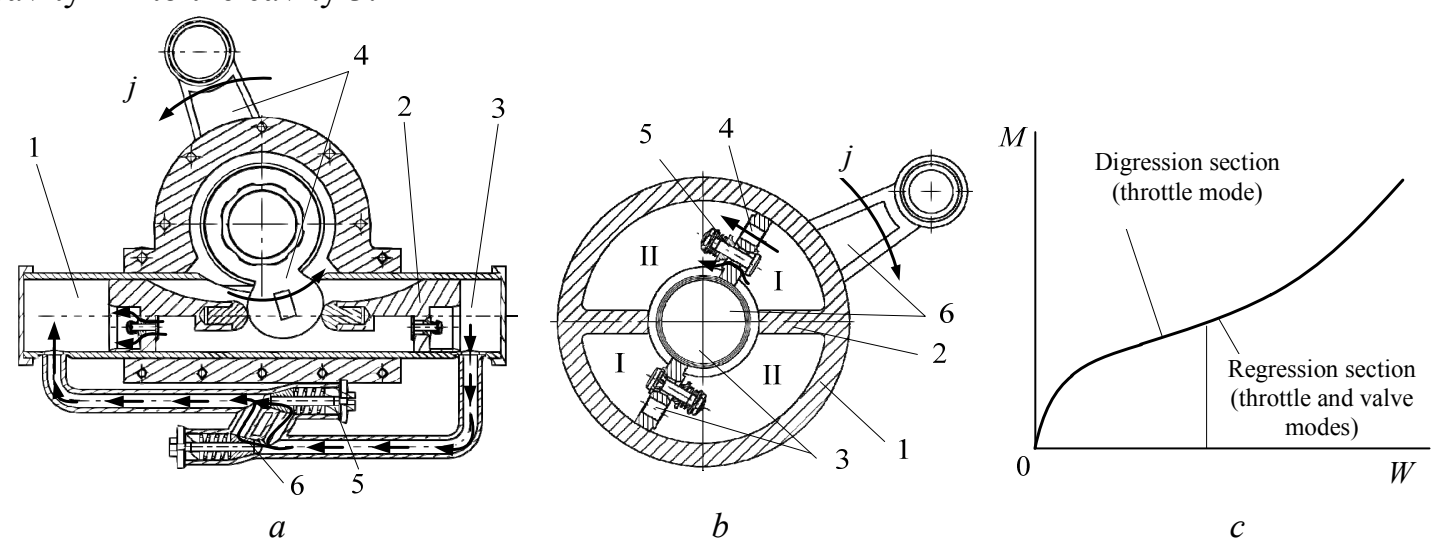

Fig. 1. Lever-type shock absorbers: piston type (a); vane type (b); performance (c)

The lever-blade damper consists of housing 1 which cylindrical bore locates a partition 2 and the shaft with vanes 3 (Fig. 1, b). The vanes bear throttle holes 4 and the forward stroke valves 5 . The continuous passage (throttle) cross-section is formed by the throttle cross section together with radial and end clearances between the blades and the housing. Lever 6 is shackle-connected to the suspension arm (the roller's rocker) when lifting and lowering thus driving the shaft and the blade 3 . When forward stroke, in the case of collision with a roughness the working fluid under a certain pressure flows from the cavity I into the cavity II through constant throttle passage section (throttle operation mode). When the pressure that determines the throttle mode increases, operated are the valves 5, thereby actuating the throttle-valve operating mode. On the return stroke the working fluid flows in the opposite direction from the cavity II into the cavity I, while the device operation is determined by the throttle mode only. Comparing the described designs, the more preferred one is the vane absorber structure, since it is more compact, has less parts number, and is well positioned in the tracked vehicles boards' special recesses.

The described designs allow implement the throttle-valve type performances, which can differ only by regression and digressive areas' inclination angle as well as their inflection point position. These figures depend on the set size of the orifice section and valves' setting. Therefore, speaking about the "ideal" performance, it should be noted that in most cases it is ideal only according to the shock absorber developer's or manufacturer's viewpoint. This is related to the known devices' functionality limits and often the device's efficiency is determined by quantitative and not qualitative indicators. For example, the shock absorber manufactured by BILSTEIN (Germany) is supplied with additional elements (spring washers for the valve), providing 52 settings for its throttle-valve operating characteristic [4].

The problem of other than throttle-valve performances implementation remains still unsolved for the known hydraulic shock absorbers (lever-vane in particular). In this regard of interest is implementation of absorber's performances control not by the cavity inner pressure, but by its mobile part displacement relative to the fixed part. This control method will make possible to determine the holonomic relationship between shock absorber's working diagram and its performance.

Aim of Research is to synthesize a principally new hydraulic lever-blade shock absorber with advanced functionality delivering the desired performance. 
Main Body. For the proposed device synthesis advised is to use the modified kinematic graph (MKG) technique. Originally this technique was developed for the analysis and synthesis of elastic systems [5]. Then it was successfully tested for the analysis and synthesis of dissipative systems, namely hydraulic piston shock absorbers $[6,7]$.

In quality of a the basic unit whose functionality is expected to expand, we consider a known lever-vane shock absorber (Fig. 1, $b$ ). Using its kinematic scheme, we construct a model in the modified kinematic graph form with corre-

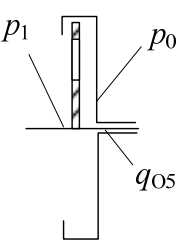

$a$

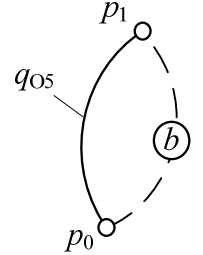

$b$

\begin{tabular}{c|c|c} 
& $q_{0}$ & $q_{1}$ \\
\hline$q_{0}$ & 0 & $5_{R} / b$ \\
\hline$q_{1}$ & $5_{R} / b$ & 0
\end{tabular}

c

Fig. 2. Modeling the lever-vane shock absorber with a modified kinematic graph: kinematic diagram (a); graph model (b); assemblage matrix (c) sponding assemblage matrix (Fig. 2)

Simulation is carried out under the condition that the synthesized mechanism is flat; $p_{i}$ - graph vertex, determining the $i^{\text {th }}$ element of the device with the appropriate numbering, $q_{5}-$ graph edge, determining the functional interaction between the device contact elements and meeting the $5^{\text {th }}$ class kinematic pairs. For more detailed model structuring the possible types of graph edges are assigned, which correspond to the rotational or translational pair ( $q_{R 5}$ and $q_{T 5}$, respectively). On the basis of the 2D-problem, the mechanism structure may include the $q_{4}$ edges, determining the functional interaction between the device contact elements and meeting the $4^{\text {th }}$ class kinematic pairs.

According to the chosen methodology the considered device model represented with MKG should form a multigraph [5]. Therefore, the model kinematic graph is modified by introducing an additional "labeled" rib $b$, corresponding in this case to the dissipative coupling, which change is directly related to the considered device kinematics, and sometimes defines it. Here, in terms of kinematics, this link is specified with a virtual analogue of $4^{\text {th }}$ class kinematic pair [6].

Degree of the resulting model mobility, based on the planar 2D problem

$$
W=3(p-1)-2 q_{5(R, T)}-q_{4}-q_{\mathrm{L}}=3(2-1)-2 \times 1-0-1=0 .
$$

Result obtained in accordance with (1) expression, reveals a close relationship between dissipative coupling properties and the considered device kinematics. This relationship may be illustrated by the following example, taking as the lever-vane shock absorber's working fluid the liquid glue, when as it is drying the device mobility becomes zero.

The cyclomatic number of the resulting model, which determines the number of cycles at flowchart with a common edge labeled $b$, corresponding dissipative coupling

$$
\sigma=q-p+1=2-2+1=1 .
$$

For the subsequent new structure synthesis necessary is to determine how exactly is supposed to control the device's dissipation. In authors' view, the most common technique, as compared to the options available for changing the working fluid properties, is the control by changing the throttle openings' area. This is implemented conventionally by using valves in conventional shock absorbers. Given that the synthesized design supposes the performance's relationship not to the pressure, but to displacement, this design excludes use of valves as useless. However, the presence of an element completely or partially overlapping throttle orifice following the kinematic law is a necessary and sufficient precondition. Having substantiated the existence of an additional movable element (valve) we approach to conclude about its contact interaction with the damper element, containing the throttle orifice. This contact can be implemented in the form of a $5^{\text {th }}$ class kinematic pair, for example, translational one.

Thus, the initial data for the new device synthesis can be considered as the next MKG set (Fig. 3, a):

— pole $p_{2}$, determining the additional component — gate, connected to the pole $p_{0}$, edge $q_{T 5}^{*}$, that corresponds to the $5^{\text {th }}$ class rectilinear kinematic pair as spoken above;

- given that the relative displacement between the gate and the housing partition with a throttle orifice defines the dissipative characteristics, poles $p_{2}$ and $p_{0}$ are connected with a "labeled" edge $b$. 


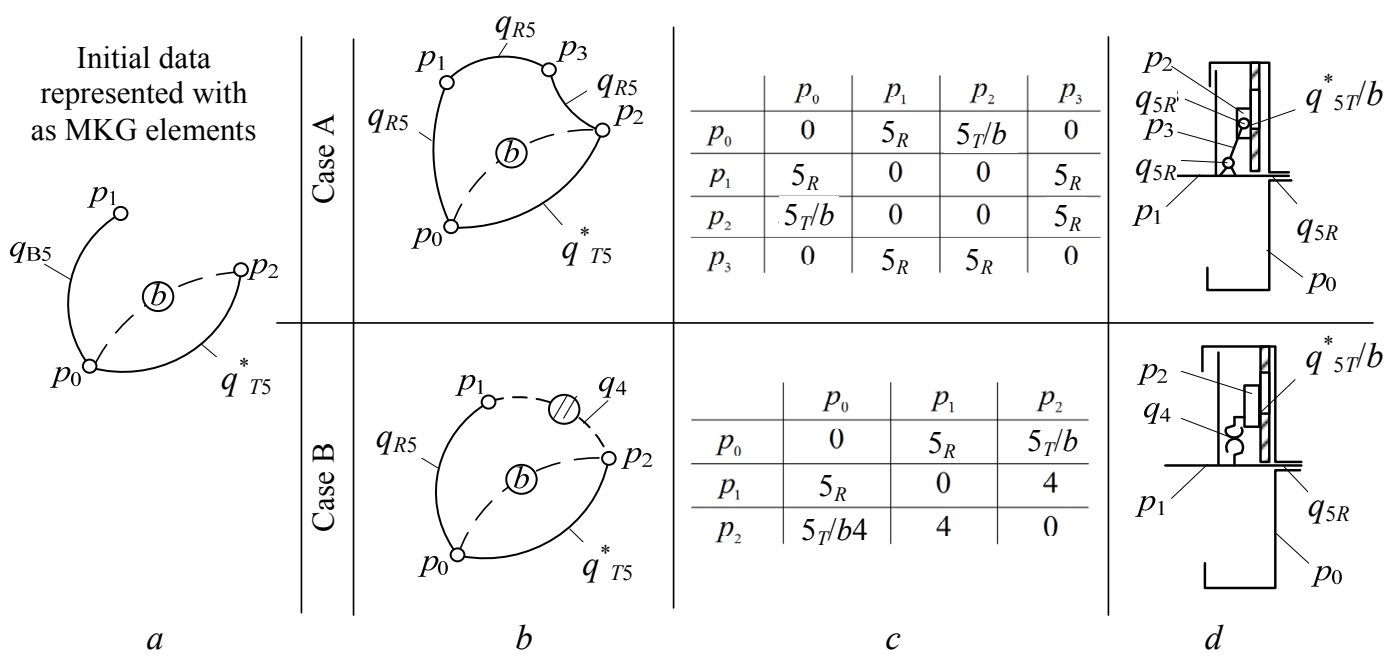

Fig. 3. Synthesis of a lever-blade shock absorber: initial synthesis data (a); MKG-represented model (b); assemblage matrix (c); kinematic diagram (d)

The synthesis problem is to determine the possible number and subsequent placement of MKG poles and ribs (basic structure extension), at that the mobility degree of the model represented with flowchart does not change, meanwhile the cycles' number becoming one more. Increase in the cycles' number as $n+1$ determines the additional mechanical control loop introducing [5]. Proceeding from this, and respecting the minimum additional elements' number condition, we get the following options for the base structure extending (Fig. 3, $b$ ):

In this case, the degree of mobility patterns of the synthesized structures in the form of the MKG:

- Case A, when the basic structure can be extended by two poles (including one $p_{2}$ pole) and three additional edges corresponding to $5^{\text {th }}$ class kinematic pairs (including $q^{*}{ }_{T 5}$ edge);

- Case B, when the basic structure can be extended by one poles ( $p_{2}$ pole) and two additional edges: one represented with $q^{*}{ }_{T 5}$ edge and another corresponding to $4^{\text {th }}$ class kinematic pairs.

At that the synthesized structures' mobility degrees expressed with MKG:

- Case A $\quad W=3(p-1)-2 q-q_{\mathrm{T}}-q_{\mathrm{L}}=3(4-1)-2 \times 4-0-1=0$;

- Case B $\quad W=3(p-1)-2 q-q_{\mathrm{T}}-q_{\mathrm{L}}=3(3-1)-2 \times 2-1-1=0$.

Models' cyclomatic numbers:

- Case A

$$
\begin{aligned}
& \sigma=q-p+1=5-4+1=2 ; \\
& \sigma=q-p+1=4-3+1=2 .
\end{aligned}
$$

- Case B

These calculations results indicate that the synthesis conditions are exactly satisfied

Results. Subsequent work with assemblage matrices on the MKG basis (Fig. 3, c) allows passing to the synthetic devices' kinematics drawing (Fig. 3, $d$ ). The obtained kinematic charts' structural design has been implemented in the form of 3D models (devices' elements designation corresponds to the legend assigned at MKG), with the auxiliary of CAD software package Autodesk Inventor Series (Fig. 4).

Checking the designed devices' structural elements kinematics and strength with the said software package we arrived to their performance efference fully confirmed. While kinematics simulation we found that the change in throttle orifices area has a close relationship with the geometric parameters of the additionally introduced structure, determining the mechanical control loop. The kinematic modeling results obtained allow suggestion on the possibility of performances' various non-linearity types implemented with the synthesized designs.

At structures' comparative analysis established is that for case A the relative twist angle of the moving part respectively to the fixed one is some less than for case B, that is due to the lever system presence in the working cavity. In addition, case A, the shock absorption rate will also vary according 
to the movable member rotation direction, due to the reduced space at lever system containing working chamber (some space taken by the lever system's body). The case B has a large twist angle, as the control system represented with a kinematically actuated cam mechanism is placed outside the working cavity. In this connection, the movable element rotation direction does not influence the shock absorption coefficient. From a technological point of view, manufacturing the case B is more complex, but the functionality - to - production cost ratio demonstrates that both samples can be considered as effective enough.

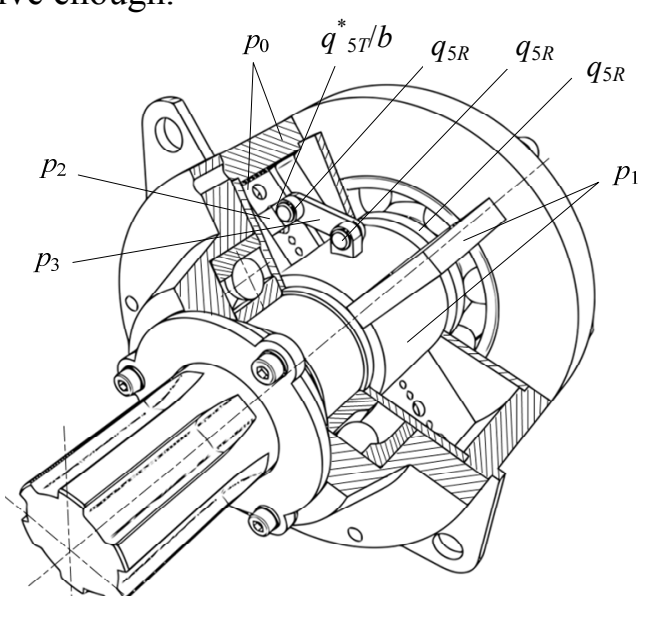

$a$

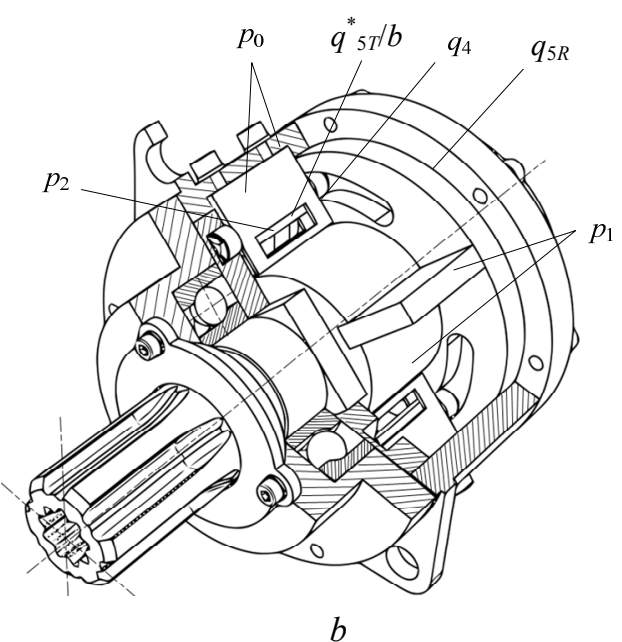

$b$

Fig. 4. Structural design appearing as 3D models, on the basis of synthesized devices' kinematic diagrams: case A (a); case B (b)

Conclusions. At the issue of research series synthesized are two fundamentally new designs of lever-vane shock absorber. Study running, it was found that:

- New shock absorbers structures are formed through adding to the basic damper structure the additional mechanical structures in the form of toggle or cam mechanisms;

- Expanding the known lever-vane shock absorber structure with additional mechanical structures is appropriate, as it allows implementing a principally new way of its performance control.

\section{Література}

1. Правда о танке Т-34: мемуары / сост.: Л. Васильева, И. Желтов, Г. Чикова. - М.: Атлантида-XXI век, 2005. - $480 \mathrm{c}$.

2. Dixon, J. The Shock Absorber Handbook / J. Dixon. - $2^{\text {nd }}$ Ed. — John Wiley \& Sons, 2007. -432 p.

3. Taylor, D. Energy management utilizing the hydraulic shock absorber [Електронний ресурс] / D. Taylor. - Taylor Devices, Inc. — Режим доступу: http://taylordevices.com/literature.html (Дата звернення: 25.11.2014).

4. Обманщиков, А. Амортизатор амортизатору... / А. Обманщиков // Автомастер. — 2005. — № 9. C. $25-26$.

5. Сидоренко, И. Пассивные виброизолирующие устройства с элементами активных систем: монография / И. Сидоренко - Saarbrücken: Palmarium Academic Publishing, 2011. — 296 c.

6. Сидоренко, И.И. Анализ структур релаксационных амортизаторов традиционными и модифицированными кинематическими графами / И.И. Сидоренко, А.Г. Баханович // Механика машин, механизмов, материалов. - 2014. - № 1. - С. 88 - 91 .

7. Сидоренко, I.I. Релаксаційний амортизатор 3 нелінійним механічним зворотним зв'язком / І.І. Сидоренко, С.І. Робу // Пр. Одес. політехн. ун-ту. — 2011. — Вип. 2(36). — С. 45 - 51.

\section{References}

1. Vasilyeva, L., Zheltov, I. and Chikova, G. (2005). Truth about T-34: Memoirs. Moscow: AtlantidaXXI vek.

2. Dixon, J. (2007). The Shock Absorber Handbook ( $2^{\text {nd }}$ ed.). Chichester, England: John Wiley \& Sons. 
3. Taylor, D. (n.d.). Energy management utilizing the hydraulic shock absorber. Taylor Devices, Inc. Retrieved from http://taylordevices.com/literature.html

4. Obmanschikov, A. (2005). There are shock-absorbers and shock-absorbers... Automaster, 9, 25-26.

5. Sidorenko, I. (2011). Passive Vibration Isolation Device with Elements of Active Systems. Saarbrücken: Palmarium Academic Publishing.

6. Sydorenko, I.I. and Bakhanovich, A.G. (2014). Analysis of the structures of relaxation conventional shock absorbers and modified kinematic graphs. Mechanics of Machines, Mechanisms and Materials, 1, 88-91.

7. Sydorenko, I.I. and Robu, S.I. (2011). Relaxation shock absorber with a nonlinear motional feedback. Odes 'kyi Politechnichnyi Universytet. Pratsi, 2, 45-51.

\section{AHOTАЦІЯ / АННОТАЦИЯ / ABSTRACT}

I.I. Сидоренко, Чжан Іхен. Синтез важільно-лопатевих амортизаторів з розширеною механічної структурою. У сучасному транспортному машинобудуванні широко поширені торсіонні підвіски. Оскільки торсіон $є$ тільки пружним елементом, то питання дисипації енергії в підвісках з його застосуванням $є$ актуальним. В даний час в якості пристроїв дисипації в торсіонних підвісках застосовують гідравлічні поршневі амортизатори 3 поступальним рухом рухомого елемента відносно корпуса або важільні гідравлічні амортизатори - поршневі і лопатеві, 3 обертальним рухом рухомого елемента відносно корпуса. Дані амортизатори реалізують робочі характеристики тільки дросельно-клапанного типу, що пов'язано з функціональними можливостями даних пристроїв, які залежать від конструктивних обмежень. В роботі проведено синтез принципово нових важільно-лопатевих амортизаторів, робоча характеристика яких не пов'язана з величиною тиску в робочій порожнині. Їх істотною відмінністю є наявність у структурі механічного контуру управління, який визначає тісний взаємозв'язок робочої характеристики з величиною переміщення рухомого елемента амортизатора відносно корпуса. У процесі синтезу проведено апробацію відповідної методики, побудованої на основі моделювання технічних систем модифікованими кінематичними графами. Результати синтезу представлені у вигляді двох конструктивно реалізованих зразків. Проведено порівняльний аналіз отриманих зразків та визначено їх основні робочі характеристики.

Ключові слова: важільно-лопатевий амортизатор, механічний контур управління, робоча характеристика амортизатора.

И.И. Сидоренко, Чжан Ихен. Синтез рычажно-лопастных амортизаторов с расширенной механической структурой. В современном транспортном машиностроении широко распространены торсионные подвески. Поскольку торсион является только упругим элементом, то вопрос диссипации энергии в подвесках с его применением является актуальным. В настоящее время в качестве устройств диссипации в торсионных подвесках применяют гидравлические поршневые амортизаторы с поступательным движением подвижного элемента относительно корпуса или рычажные гидравлические амортизаторы - поршневые и лопастные, с вращательным движением подвижного элемента относительно корпуса. Данные амортизаторы реализуют рабочие характеристики только дроссельноклапанного типа, что связано с функциональными возможностями данных устройств, зависящих от конструктивных ограничений. В работе проведен синтез принципиально новых рычажно-лопастных амортизаторов, рабочая характеристика которых не связана с величиной давления в рабочей полости. Их существенным отличием является наличие в структуре механического контура управления, который определяет тесную взаимосвязь рабочей характеристики с величиной перемещения подвижного элемента амортизатора относительно корпуса. В процессе синтеза проведена апробация соответствующей методики, построенной на основе моделирования технических систем модифицированными кинематическими графами. Результаты синтеза представлены в виде двух конструктивно реализованных образцов. Проведен сравнительный анализ полученных образцов и определены их основные рабочие характеристики.

Ключевые слова: рычажно-лопастной амортизатор, механический контур управления, рабочая характеристика амортизатора.

I.I. Sydorenko, Zhang Yi Heng. Synthesis of lever-blade dampers with enhanced mechanical structure. The torsion suspension is a widespread structure in today's transport machine engineering. Since the torsion bar represents just an elastic element, the energy dissipation in suspensions problem is highly relevant for its application. Currently in quality of a dissipation device in torsion suspension are used the hydraulic dampers with movable member's reciprocating translational motion respectively to the housing or lever-type hydraulic shock absorbers of piston and vane types, with the movable member's rotational movement respectively to the housing. These dampers are implementing only throttle-valve performance type, associated with these devices' functional capacities and depending on design constraints. The paper presents a synthesis of innovative lever-blade dampers, whose performance is not related to the value of working chamber's inner pressure. Their essential peculiarity relates to the mechanical control loop presence in the structure that determines a close relationship between the performance and the value of the shock absorber movable element displacement relatively to the body. In the process of synthesis carried out tested are the appropriate methods, built on the basis of technical systems' modeling with modified kinematic graphs. The synthesis results are shown in the form of two structurally implemented samples. Performed is a comparative analysis of the samples with their basic performance determining.

Keywords: lever-blade damper, mechanical control loop, shock absorber performance.

Received December 1, 2014. 